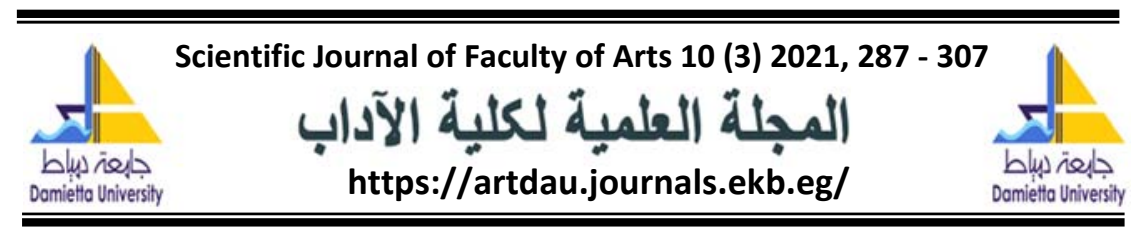

\title{
Transitivity and Modality Analytic Processes of Donald Trump's Speech on Death of Baghdadi
}

\section{Mohamed Saeed Shafeek Mobarak}

Phd student, English Department, Faculty of Arts, Damietta University.

\section{Abstract}

Considered an inter-discipline that is associated with the study of the linguistic relationship of power and ideology, critical discourse analysis (CDA) attracts more and more attention to be easily applied to analyze linguistic features through some certain social and cultural background. CDA is built upon Halliday's systemic functional grammar (SFG) that is considered to be a practical method to analyze discourse. As a kind of typical discourse combining the speaker's ideology and intention, political discourse can be analyzed by CDA. Accordingly, this research analyzes Donald Trump's, the ex-American president, speech about AlBaghdady mainly from the perspectives of transitivity and modality with the aim of revealing the speaker's political intention. The research concludes that Trump uses different linguistic alternations to transmit, change, and retain audiences' ideologies. Further, it attains a positive impact upon the CDA's development.

\section{Keywords:}

Baghdady, linguistic relationship.

\section{Article history:}

Received 19 May 2021.

Received in revised form 1 July 2021.

Accepted 25 July 2021. 


\section{Introductions}

Everyone takes a lot of precautions in choosing the most appropriate sentence structures in addition to certain lexemes so as to win some favorite responses. Despite their distinctive positions, politicians make no exceptions. Speech-makers have a well-built command of linguistic manipulation skills so as to have some persuasive choices for moving the public to accept and advocate such related policies. In contrast, dictators are those persons who take mostly advantage of this in order to encode skill effectively to path a legal track for their government.

However, people usually listen to them even when they feel mistaken since language has an influential role as a vehicle to convey a message and end justifications. Through CDA view point, a dictator can be termed as:

- a person who conceives himself to be the superpower over others accepting no intellectuality,

- a person who fears from letting people free so as to dominate their lives

- a person who does anything but ruling only for the sake of ruling. (Farhat, 2016).

\section{Statement of the Problem}

Discursive policies of presidential majesty, all over the world, are replete with rich sources of data collection in the domain of applied linguistics. The essential argument is that politicians try to highlight their words to recognize that the public are, de facto, listening to them. Analyzing presidential speech is to provide mediations and reflections of their thoughts, notions, and intentions.

Today, the Muslim world is in the scope of accumulated accusations and stuck challenges which spring up from either external or internal issues. Built upon the notion of SFL, people arrange their speech in terms of vocabulary and grammar as lexical choices when they speak. Accordingly, the current study sheds light on the lexicogrammatical choices in relation to the so-meant text of Trump's speech, the ex-American president. 


\section{Significance of the Study}

The current study is associated with the contribution of the mutual intelligibility across the views and notions of Donald Trump, the ex-American president, through the exploration of his representations of both Transitivity process (events, ongoing actions, etc.) in addition to the elements included within participants (people and governments) who are involved in the process of discourse as a major part of the experiential meaning. Furthermore, the study's significance is associated with Donald's judgments and assessments of what he says as a considerable part of the interpersonal meaning. On the other hand, CDA aims at denaturalizing concealed abusive power relationships as well as some ideological processes embedded in the text.

\section{Theoretical Framework}

This section sheds light on a theoretical framework of CDA regarding its origins, evolution, definitions, and various approaches. Moreover, the current section highlights Halliday's (2014) Systemic-functional Linguistic (SFL) approach in terms of its lexico-grammatical choices in addition to modality and transitivity systems as a part of its experiential meaning.

\subsection{Critical Discourse Analysis (CDA)}

According to Wodak and Meyer (2001), critical science needs a lot of further questions which are associated with interests, responsibility, and ideological terms beyond either any scientific descriptions or superficial applications. Instead of concentrating on theoretical problems, it springs from the most prominent social problems, so as to pick up the perspective of those who lead miserable life most to be critically analyzed in terms of power, responsibility, and ideological terms with the aim of solving such problems.

Within the late1970s, Roger Fowler and some other pioneers(Fowler et al., 1979b) have felt that linguists have been committed to an objective description concerned with language, shedding light on investigating questions as "what" despite ignoring questions namely "why" and "how" in language and its use. 
Kress (1990) and Fairclough (1989) claim that both the social and historical background of the discourse in addition to the processes of event should not be ignored within such a linguistic analysis. Therefore, they make an enquiry configuring the relationship across signs, meaning and the social and historical conditions, all of which are existent to be inextricably associated with the speaker or writer's thought. Gradually, the certain investigation into the relationship across language and ideology evolves into the critical discourse analysis.

During CDA's emergence in 1970s, the relationship between language and ideology has been its central topic. Hodge and Kress (1988) claim that language is considered to be the primary source of ideology; in the sense that members of a society are on full awareness of it on their use of language within their daily lives course. Van Dijk (1986), Fairclough (1989), and Fowler (1991) say that even the apparently "unbiased" news language does not, transparently and objectively, symbolize "facts"; however, they are ideological and in the same time they are also related to the core of the values, beliefs and practice of their social contexts in various ways.

CDA highlights social issues and demonstrates special interests in the influential role of media discourses regarding their production of power abuse and domination of the ideological style of dominant groups. According to Van Dijk (1995), the media, ideological institutions, takes over the ideological work of the social sets namely family, the church, and the school in contemporary society. Van Dijk (1986) relates his analysis to the news reports which are associated with the coverage of refugees, immigrants and minorities with the aim of examining news media role in the reproduction of ethnic prejudices and racism.

In spite of CDA's various theoretical approaches, most critical discourse analysts have an exchangeable vision of inner linguistic centrality as a means of social construction. Kress (1989), in Wodak (2001), puts forth some major assumptions of CDA as clarified below: 
- Language is considered to be a social phenomenon,

- Both individuals and social groupings have specific meanings and values portrayed in systematic linguistic methods,

- Texts are the major units of language within communication channels,

\subsection{The Concept of SFL}

Systemic-Functional Linguistics (SFL) is considered to be a linguistic approach developed initially by M.A.K. Halliday during the 1960s. It was initially set its origins in UK and later in Australia. The SFL approach is then applied nowadays for some new strategies of teaching and learning in schools and educational institutions due to its grammatical relatedness. Also, it is applied with the aim of discourse analysis by researchers. Halliday, (2004) in his work on SFL, refers to language as meanings rather than a combination of words and sentences strings. It interprets how language is used in terms of social contexts so as to achieve particular objectives.

According to Halliday (1994), language is seen as a system of meaning potential; in addition, any linguistic meanings are acknowledged through its forms, in the sense that, there should be grammatical structures related to meaning which he called as systemic functional grammar. SFG is not considered to be such a grammatical structure orientation; however, it is associated with exploring meanings. Thus, Systemic Functional Grammar (SFG) is a considerable form of grammatical and meaningful description. Moreover, it is an essential part of the systemic functional linguistics which is thought to be a social semiotic approach.

Based on Halliday and Matthiessen (2004), a systemic grammatical approach highlights the paradigm; systemic grammars basically set out the lexical choices available within a particular linguistic context. In other words, it is related primarily to the grammatical choices which are abundant within the language user so he/she has the ability to select the appropriate choices inside the 
suitable context. Halliday and Mathieson (2014) explain that, in SFL, language is categorized according to three strata: semantics, phonology, and lexico-grammar. He regards language in terms of its structure (grammar) and words (lexis). The dual meeting of both leads to what Halliday calls lexico-grammar.

Halliday and Matthiessen (2014) identify language as a text, system, sound (phonology), writing and wording (orthography), and a resource of alternative choices (lexis). He suggests the essential semiotic dimensions which encapsulate the architecture of any language in terms of context, structure, system, stratification, and meta-functions. The current research sheds light on meta-function analysis. Meta-function is a considerable term which Halliday uses to identify the linguistic functions of a context. According to such perspective, he suggests that forming and framing experience in addition to acting out people's social relationship are considerably basic in any communication. This means that language provides a theory of human experience; such linguistic function is called to be ideational function which includes both the experiential meta-function and logical meta-function.

Transitivity analysis becomes one of the major tools to conduct Critical Discourse Analysis (CDA). This category of analysis is offered through the theory of Systemic Functional Linguistics (SFL), initiated by Halliday, so as to analyze a text; its ideological form can be demonstrated. According to Matthiessen and Halliday (1997), grammar in SFL identifies the resource for making up meanings through wordings. The linguistic occurrence of elements creates miscellaneous interpretations. In such creation for the meanings intended, grammar can be introduced within tripartial meta-functions process: ideational (field), interpersonal (tenor), and textual (mode).

Within transitivity analysis, there are six considerably-categorized processes: material, verbal, mental, relational, behavioral, and existential. To acknowledge each process, the main factor to be regarded is the verb which is 
the tool to determine the category of each process. Material verbs identify the material process; however, verbal verbs categorize the verbal process. Mental verbs denote the mental process. In terms of linking verbs, they mark the relational process, whereas behavioral verbs mark the behavioral process. The empty subject "there" and the nonreferent "it", followed by the copulative structure, mark the existential process. Each process is also formulated by its participants.

- The material process has Actor, Goal, and Affected participants.

- The verbal process has Sayer, Receiver, and Verbiage participants.

- The mental process has Senser and Phenomenon participants.

- The relational process has Carrier-Attribute, Identifier Identified, and Possessor-Possessed participants.

- The behavioral process has Behaver participant.

- The existential process has Existent participant.

In addition, the textual meaning is associated with the organization of the text message. Regarding the current research, two meta-functional processes are regarded to focus on: the experiential and interpersonal. Two systems are selected to realize them.

- Transitivity is the considerable tool to reveal the experiential meaning in the speech of Donald trump within the so-meant speech speech.

- Modality is also considerable relation of the tool with the aim of exploring inner structure of the hidden messages across the speaker (Trump) and the addressee (audience). The following section demonstrates the systems of Transitivity and Modality respectively.

\subsection{Transitivity System as Experiential Meaning}

In SFL, Transitivity is seen as a domain of the experiential meta-function inside the clause (Halliday \& Matthiessen, 2014). Halliday and Matthiessen (2014) identify Transitivity as the core system of clarifying people's 
experience. When the clause identifies the so-intended function as an experiential meaning, the current events in the world are to be represented through the processes semantic concerned with structures which are acknowledged by the verbal group included within the clause.

In traditional grammar, processes are treated as the core of verbs whereas the participants are viewed as subjects and objects within the clause identifying the syntactic structure; however, in modern grammar, processes and participants' concepts refer to the functional structures of the clause. Halliday and Matthiessen (2014) point out that any clause should have tri-elementary components:

- A process which is to be revealed through time.

- The participants who are to be included within the process.

- Circumstances which are to be interlinked with the process.

According to Halliday and Matthiessen (2014), the three components are considerably arranged in a configurative method, that is to say, it has to provide the models or schema of manifesting our experience concerning what takes place within surroundings.

The current research is conducted to explore the processes and participants' elements with the exclusion of any circumstantial elements which are incrementally optional inside the clause rather than any obligatory components. In sharp contrast, the participants are considered to be inherent inside the process (Halliday \& Matthiessen, 2014).

The current study aims at exploring the processes in addition to whom or what are involved within such aforementioned processes within the context of Trump's speech. Thus, time, location and manner expressions, acknowledged through the circumstantial elements, are not essential within this research. Circumstantial elements operate on strengthening the process temporally, spatially and so on (Halliday \& Matthiessen, 2014). 


\subsection{Types of Transitivity Processes and Participants Elements}

Clauses processes are categorized out into three main types: Material, Mental and Verbal processes, whereas there are subtypes, sprung from mutual features of the major processes, included in Relational, Behavioral and Existential sub-processes. Each of these processes has its unique participants that play various roles inside the clause (Halliday \& Mathiessen, 2014). Moreover, Thompson (2004, 2014), Eggins (2004), and Fontaine (2013) sort clause processes out according to Halliday's (2014) categorization. Regarding these types of process, the participants are considerably categorized. Also, each process has its unique participants who serve some specific functions.

\subsubsection{Material Process and Participants}

When the process, within the clause, renders the experience of both events and actions, it is considered to be called Material Process (Halliday \& Matthiessen, 2014). Any Material process shall include the Actor's participant who functions as the process doer. Moreover, it may have the Goal's participant that is affected by the process (Thompson, 2004). There are two other categories of participants, having the same function of Goal of being influenced upon by the process: Beneficiary and Scope. Beneficiary is deemed to be the participant who benefits from the process whereas Scope describes the process domain (Fontaine, 2013).

\subsubsection{Mental Process and Participants}

The Mental process is a considerably sensitive-built process. While external experience is presented through Material processes, the internal experience is formulated through the Mental process (Halliday \& Matthiessen, 2014). Two participants are included to operate within this process: Senser that does the function of sensing and Phenomenon which is the thing sensed. Phenomenon participant can be demonstrated in a person, a concrete object, or a fact (Halliday \& Matthiessen, 2014). Halliday \& Matthiessen (2014) divide the Mental processes into four types, perceptive, cognitive, desiderative and emotive. 
Relational process characterizes or identifies some certain features (Halliday \& Matthiessen, 2014). There are certain verbs, included within such a process, namely verbs to "be" in addition to its syntactic categories such as "appear", "seem", "look", and "become" in addition to the possession verbs such as "have", "own", and "possess". There are two involved types of Relational processes namely Attributive and Identifying. Their difference lies in the roles of their participants in addition to the function they provide inside the clause. The Relational attributive process is associated with the description of a case or situation; however, it does not identify it. Clearly, it attributes something to some certain entity (Bloor \& Bloor, 2004).

The Attributive Relational process is formulated of two participants: Carrier and Attribute. Within some cases, the Attributive process is acknowledged as a Possessive process on condition that the process shows possession or ownership. Regarding Bloor \& Bloor (2014), the participants are the considerable Possessor and the possessed. According to Halliday and Matthiessen (2014), the second function of Relational process is attained through its identification and implicatures. It contains the way of showing something through something else. Both Token and Value are namely involved inside the process. They are used so as to identify the other (Halliday \& Matthiessen, 2014).

\subsubsection{Verbal Process and Participants}

The verbal process refers to the action of saying. It is associated with three participants. The fist participant is considered to be the Sayer indicating the producer of what is said. The second participant is considered the Verbiage indicating what is said. According to the third participant, Target identifies the entity to which the utterance is ascribed. All verbs of utterances and messages production, either written or spoken, are to be involved within this process such as "declare", "explain", "say", "repeat", and "tell".

\subsubsection{Behavioral Process and Participants}

Behavioral Processes are related to human physiological and psychological behavior, such as 
breathing, coughing, smiling, dreaming and gazing (Halliday $\&$ Matthiessen, 2014). The first participant of this process is Behaver, the entity behaving, whereas the other participant is called the Behavior or Range. It operates as it is in the case of the scope participant in the material process.

\subsubsection{Existential Process and Participants}

Existential process is considered to be the simplest process regarding its structure. This process intermediates the range across material and relational processes. It is called existential as it sheds light on representing the phenomenon of existence within the clause. The existential process is only existent in a unitary form of clause structure, with the existence of verb (Be) and subject there (Fontaine, 2013). The participant, here, is that one called existent which represents the thing existent.

\subsection{MODALITY SYSTEM as a FRAMEWORK OF INTERPERSONAL MEANING}

The Modality, as an analytical tool used within the current study, reveals the interpersonal meaning as proposed by Halliday $(1985,1994)$, and Halliday and Matthiessen (2004, 2014). The interpersonal meta-function of language is not restricted to exchanging utterances process across the speaker and listener, but it also contributes to establishing a meaning through speaker's judgments and opinions expressions within the clause towards the discourse topics. This function can be acknowledged through the Modality choices (Halliday \& Matthiessen, 2014).

According to Halliday (2014), modality is considered to be a part of Mood. Mood is the component within the clause via which the speech role is interpreted. When the clause is produced by the speaker with the aim of exchanging information through statements and questions, it takes the structure of a proposition; however, when it is used for exchanging goods and services via offers, it is known as a proposal.

Halliday \& Matthiessen (2014) define Modality as the validity of what is predicated, pointed out, questioned, informed or offered in the clause, on the other hand, it can 
demonstrate the relationship of social role. Modality can be, semantically, presented through looking at its types which can be expressed by both modal verbs and adjuncts (Fontaine, 2013).

In view of SFL's Modality, Halliday and Matthiessen (2014) differentiate across two types of Modality: Modalization and Modulation. Both of the two sorts have sub-categories and various values to express what across between yes and no. This sorting comes due to the type of clause either propositional or proposal. If the utterance is considered to be a proposition, then the modality interprets how valid the information is to be introduced within the clause, usually expressed in probability and usuality forms. On the other hand, if the clause is considered to be a proposal, then Modality is concerned with the degrees of Obligation or Inclination to accomplish the command (Halliday \& Matthiessen, 2014).

\subsection{Types of Modality}

The types of modality are explained in the following sub-sections:

\subsubsection{Modalization}

According to Halliday and Matthiessen (2014), when people interact with each other in order to exchange information through statements or questions, clauses semantic form is considered to be called proposition. Halliday \& Matthiessen (2014) define the term proposition as the thing which is intended to be either argued about, affirmed or denied. There are two types of intermediate possibilities which are used in propositions. The first type is concerned with degrees of Probability which is related to likelihood judgments whereas the second type is related to degrees of Usuality which is related to ofteness judgments namely frequencies of what occurs, occurred and will occur.

Halliday and Matthiessen (2014) point out that there are two scales of Modalization namely Probability and Usuality; in addition, Modalization can be introduced within three forms. Regarding point, both Probability and Usuality are expressed by a finite modal operator within the verbal 
group, a modal adjunct of either probability or usuality, and an eclectic type forming prosody of modalization

\subsubsection{Modulation}

Proposal is a clausal form when it aims to exchange services. There are two categories of possibility degrees regarding the function of speech either to offer or command (Halliday \& Matthiessen, 2014). Within commands, the intermediate values express Obligation items; for example, 'you must go' expresses obligatory instructions whereas in offers the intermediate degrees express Inclination; 'I'd like to go'. Both scales of Inclination and Obligation are categorized as Modulation. Halliday and Matthiessen (2014) observe that both Obligation and Inclination are identified by Modal verbs such as 'I must go', 'He should go' as a Mood part. Also, it is expressed as predicator.

Fontaine, (2013) defines Modulation as a category of connotative meaning which is related to obligation or permission, including both willingness and ability. Thus, Modulation is expressed by the clauses which embody Obligation or Inclination (Halliday and Matthiessen, 2014).

\subsection{Degrees of Modalization and Modulation}

Halliday and Matthiessen (2014) point out that there are three degrees in which Modality choices are considerably expressed. This can identify how much the speaker is doubtful about what he suggests either in propositions or proposals. It is noted how some of modality expressions included in 'will, must, and can' are fond in the aforementioned tables concerned with Modalization and Modulation. Halliday \& Matthiessen (2014) indicate that the so-meant model expressions include various functions as Modality choices, in other words, they can express Modalization and Modulation.

Modalization is not only expressed in modal verbs but also adjuncts of Probability and Usuality. Halliday and Matthiessen (2014) describe Modulation in accordance with its representation in modal verbs only; this mirrors the use of Modulation within the clause Mood part. Thompson (2014) provides examples of modal verbs which refer to both types 
of Modality forms, based on their degrees which Halliday \& Matthiessen introduce (2014).

Based Halliday and Matthiessen's (1999) view, Modality is a resource for speakers to intrude their own discourse views, their typical assessments, and their judgments of the rights and wrongs of the situation and of where other people stand in this regard.

\subsection{Research Methodologies}

The data included within the current study is represented in the form of clauses according to the victory speech of Baghdadi's death delivered by the exAmerican president Donald Trump. The so-meant speech is made in the period in 2019 to treat various issues. The speech is in the form of written texts (transcripts); it is collected from BBC's electric magazine website. A collection of the so-meant transitivity and modality processes is held across the contents of the speech through the original videos of Trump's speech to conform to the originality of the written texts.

\section{Data Analysis}

This section sheds light on analyzing data within the so-meant speech. Only few samples are chosen as the someant items. Only three processes are associated namely material, mental and relational.

\subsection{Material Processes and Participants}

The following table demonstrates the material process and its participants included within the texts included. 
Table 1 Material Processes and Participants

\begin{tabular}{|c|c|c|c|c|}
\hline $\mathbf{N}$ & Actor & Process & Beneficiary & Goal \\
\hline 1 & $\begin{array}{l}\text { The United } \\
\text { States }\end{array}$ & brought & $\begin{array}{l}\text { the world's } \\
\text { number one } \\
\text { terrorist leader }\end{array}$ & $\begin{array}{l}\text { to } \\
\text { justice }\end{array}$ \\
\hline 2 & $\begin{array}{l}\text { The United } \\
\text { States }\end{array}$ & $\begin{array}{l}\text { has been } \\
\text { searching }\end{array}$ & $\begin{array}{l}\text { for Baghdadi } \\
\text { for many years }\end{array}$ & \\
\hline 3 & $\begin{array}{l}\text { U.S. } \\
\text { Special } \\
\text { Operations } \\
\text { forces }\end{array}$ & executed & & $\begin{array}{l}\text { a dangerous } \\
\text { and daring } \\
\text { nighttime raid }\end{array}$ \\
\hline 4 & $\mathrm{He}$ & reached & & $\begin{array}{l}\text { the end of the } \\
\text { tunnel }\end{array}$ \\
\hline$E$ & $\mathrm{He}$ & ignited & his vest & \\
\hline 6 & test results & gave & $\begin{array}{l}\text { positive } \\
\text { identification }\end{array}$ & \\
\hline 7 & $\begin{array}{l}\text { Baghdadi's } \\
\text { demise }\end{array}$ & demonstrates & & $\begin{array}{l}\text { America's } \\
\text { relentless } \\
\text { pursuit of } \\
\text { terrorist } \\
\text { leaders } \\
\end{array}$ \\
\hline 8 & $\mathrm{We}$ & will destroy & & them \\
\hline 9 & $\begin{array}{l}\text { These } \\
\text { monsters }\end{array}$ & will not escape & their fate & \\
\hline 10 & They & will not escape & $\begin{array}{l}\text { the final } \\
\text { judgement of } \\
\text { God }\end{array}$ & \\
\hline
\end{tabular}

According to the aforementioned table, there are ten clauses which identify the material process included within the speech. The first clause refers to the United States' capacity of brining the most dangerous terrorist. In terms of the second clause, it identifies the ongoing search of the United States of Baghdadi who caused a lot of troubles during his life. The third clause admits the U.S. Special Forces' execution of killing Baghdadi during a nighttime raid. Both the four clauses infer the scenes of the sad end of Baghdadi. Clause no (7) also identifies his demonstration of sudden death. Both the ninth and the tenth clauses report the fatal ends of the pronoun "they" who is described as monsters. Trump within the speech comments on such punishment either in life or at the Doomsday. 


\subsection{Mental Process}

The following table demonstrates the mental process and its participants included within the texts included.

Table 2 Mental Process

\begin{tabular}{|l|l|l|l|}
\hline $\mathbf{N}$ & Senser & \multicolumn{1}{|c|}{ Desiderative } & \multicolumn{1}{c|}{ Phenomenon } \\
\hline 1 & I & want to & $\begin{array}{l}\text { thank the nations of Russia, Turkey, } \\
\text { Syria and Iraq }\end{array}$ \\
\hline 2 & I & also want to & $\begin{array}{l}\text { thank the Syrian Kurds for certain } \\
\text { support they were able to give us }\end{array}$ \\
\hline 3 & I & want to & $\begin{array}{l}\text { thank the soldiers, sailors, airmen, and } \\
\text { marines }\end{array}$ \\
\hline
\end{tabular}

It is notable that there are only three clauses included within the entire text. Such clauses exhibit the verb "want" which identify the desiderative. All the three clauses are headed by the first person plural "I" as an identification of the thanking process for Russia, Turkey, and Iraq. Moreover, thanking is orientated to the Kurdish forces contributing too much to controlling their first raid on Baghdadi.

\subsection{Relational Process}

The following table demonstrates the relational process and its participants included within the texts included. Such a linguistic process is divided into attributive and possession processes. However, the current extracted clauses only infer the relational process.

Table 3 Relational Process

\begin{tabular}{|l|l|l|l|}
\hline $\mathrm{N}$ & Carrier & Attributive & Attribute \\
\hline 1 & $\begin{array}{l}\text { Abu Bakr al- } \\
\text { Baghdadi }\end{array}$ & is & Dead \\
\hline 2 & He & was & $\begin{array}{l}\text { the founder and leader of ISIS } \\
\text { of my Administration }\end{array}$ \\
\hline 3 & killing Baghdadi & has been & lost in the operation \\
\hline 4 & $\begin{array}{l}\text { No U.S. } \\
\text { personnel }\end{array}$ & were & Baghdadi in the tunnel \\
remaining only ones & were & $\begin{array}{l}\text { in the compound for } \\
\text { approximately 2 hours }\end{array}$ \\
\hline 6 & $\begin{array}{l}\text { We reach of } \\
7\end{array}$ & $\begin{array}{l}\text { The ren } \\
\text { America }\end{array}$ & Long \\
\hline 8 & Baghdadi & has been & on the run for many years \\
\hline
\end{tabular}


Regarding the previous table, there are eight extracted clauses four of which identify the death of Baghdadi and his final scene of fatal death. The first clause reports the use of the present simple tense of verb to "be" which expresses a real fact of a current matter. The second clause reports that Baghdadi is the founder of Islamic State in Syria (ISIS) which Trump uses as an acronym too much during his speech. Killing Baghdadi is the main priority of his administration; nothing is more important than bringing and killing him. However, there are three clauses all of which identify the safety and stability of the Americans and America. In terms of the fourth clause, none within the US Special Forces is hurt. The use of the first person plural "we" denotes the plurality of attaining such a great action. Nonetheless, in the seventh clause, seeking for destroying America is far-reached.

\subsection{Modality Process}

In terms of modality process, there are two types: modalization and modulation. Halliday and Matthiessen (2014) define modalization as a process in which information is to be exchanged through statements or questions. There are some clauses extracted within the sointended text as shown below in the following table

Table 4 Modality Process

\begin{tabular}{|l|l|}
\hline Modality Clause & Indication \\
\hline - $\quad$ Terrorists should never sleep soundly & Median \\
- $\quad$ These savage monsters will not escape their & Probability \\
fate & Median \\
- They will not escape the final judgement of & Median \\
God. & Probability \\
- We will continue to pursue the remaining ISIS & Median \\
terrorists to their end. & Probability \\
- He will never again harm another innocent & Median \\
man, woman or child. & Probability \\
& Low Probability \\
\hline
\end{tabular}

There is only an apparent and dominated operator used within the modality process; it is the future simple reference auxiliary verb "will". According to Halliday (2014), the use of median probability refers to the speaker's 
intention of sending his message to the entire audience. The six aforementioned clauses indicate the speech about the terrorists and their fatal death. In the first clause, Trump asserts the fact of non-comfortable sleeping for the terrorists. Followed by the second clause, he highlights the tightened fist of killing them and chasing them forever. The third clause describes them as "monsters" who cannot escape their fate even on the Judgment day. The use of the first person plural pronoun "We" asserts his inner acquisitions and the collective strength in tracing any terrorist belonging to the ISIS. The last clause resorts to the feeling of safety and comfort due to Baghdadi's death on the Special Forces of the United States.

Table 5 Modulation Process

\begin{tabular}{|l|l|}
\hline \multicolumn{1}{|c|}{ Modulation Clause } & \multicolumn{1}{|c|}{ Indication } \\
\hline - I want to thank the nations of Russia, Turkey, & Median \\
Syria and Iraq. & Obligation \\
- I also want to thank the Syrian Kurds for & Median \\
certain support they were able to give us. & Obligation \\
- I also want to thank our professionals who & \\
$\begin{array}{l}\text { work in other agencies of the United States } \\
\text { government and were critical to the mission's }\end{array}$ & Median \\
$\begin{array}{l}\text { success. } \\
\text { I want to thank the soldiers, sailors, airmen, } \\
\text { and marines involved in last night's operation. }\end{array}$ & Median \\
& Obligation \\
\hline
\end{tabular}

According to the previous table, there are four clauses referring to the obligatory mood of modulation. Only the operator "want" refers to the state. It is notable that the four clauses are headed by "I" indicating the character of Donald Trump in a trial of throwing thanking and blessing over the co-allies and his special forces so as to set confidence in his allies.

\section{Conclusion}

Transitivity analysis portrays an ambivalent image about the personality and intentions of Trump because his concern stands against the Muslim world. His informative presentation of truths regarding the issues through the various types of processes makes people connived of him 
and accept his views. Choices and degrees of Modality reveal the interaction between Trump president and his audience, in addition to his opinions on the topic discussed. Therefore; the interpersonal meaning is acknowledged. Furthermore, the use of Probability and Usuality contributes to interlinking the relationship between the president and audience.

\section{REFERNCES}

Bloor, T., \& Bloor, M. (2013). The Functional Analysis of English: A Hallidyan Approach.

Eggins, S. (2004). An Introduction to Systemic Functional Linguistics (2nd Edition.). London/ New York: Continuum International Publishing Group.

Fairclough, N. (1989). Language and Power. London: Longman.

Farhat, F. M. (2016). A Systemic Linguistic Analysis of Process Types, Participant Roles and Modality Types in Obama's Speeches on Muslim World Issues (Doctoral dissertation, , Bahasa Faculty of Linguistics, University of Malaya).

Fontaine, L. (2013). Analyzing English Grammar: A Systemic Functional Introduction. New York: Cambridge University Press.

Fowler, R. (1991). Language in the News. London/ New York: Longman.

Fowler, R., et al. (1979b). Language and Control. London: Routledge \& Kegan Paul.

Halliday, M. A. (1990). New Ways of Meaning: The Challenge to Applied Linguistics. Thirty Years of Linguistic Evolution, 59-95.

Halliday, M. A. K. (1994). Language in a Changing World:

Applied Linguistics Association of Australia.

Halliday, M. A., \& Christian, M. I. M. Matthiessen. (2004). An Introduction to Functional Grammar, 3.

Halliday, M.A.K. \& Matthiessen C. (2014). An Introduction to Functional Grammar (3rd Edition). London and New York: Routledge. 
Halliday, M.A.K. (1961) "Categories of the Theory of Grammar". Word 17. Reprinted in Halliday, M.A.K. and Jonathan Webster (2002) On Grammar (Collected Works of M.A.K. Halliday, Vol. 1). Edited by Jonathan Webster. Continuum.

Halliday, M.A.K. (1985). An Introduction to Functional Grammar. London: Edward Arnold.

Halliday, M.A.K. and Matthiessen, Christian M.I.M. (2004) An Introduction to Functional Grammar: $3^{\text {rd }}$ Edition. London: Hodder Education. Print.

Hodge, R., \& Kress, G. (1988). Social Semiotic. Cambridge: Polity Press.

Kress, G. (1990). Linguistic Processes in Sociocultural Practice. Oxford: Oxford University Press.

Matthiessen, C. and Halliday, M.A.K. (2011) Systemic Functional Grammar: A First Step into the Theory. 1997

Thompson, G. (2004) .Introducing Functional Grammar (Second Edition ed.). London Arnold.

Van Dijik, T. A. (1995). Discourse Analysis as Ideology Analysis. In C. Schaffner \& L. Anita (Eds.), Language and Peace (pp. 47-142). Weenden Dartmouth: Aldershot.

Van Dijk, T. A. (1986). Racism in the Press. London: Edward Arnold Ltd.

Wodak, R. (1989). Language, Power and Ideology: Studies in Political Discourse. Amsterdam/Philadelphia: John Benjamin's.

Wodak, R. (1995). Critical Linguistics and Critical Discourse Analysis. In J. Verschuren et al. (Eds.), A handbook of pragmatics-manual (pp.139-198). Amsterdan/Philadephia: John Bejiamins Publishing Company 


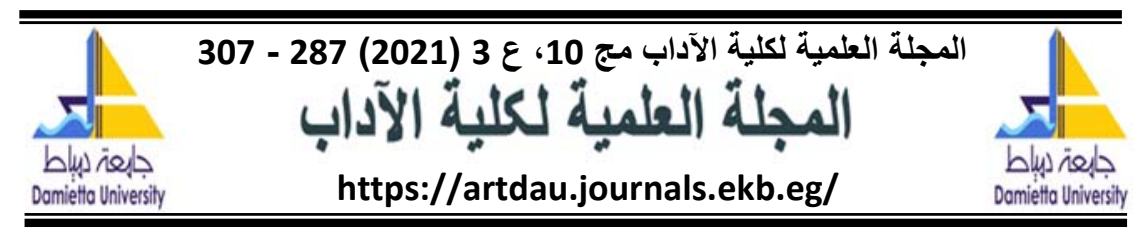

\section{التعددية والتشكيلية كعمليات تحليلية في خطاب دونالد ترامب

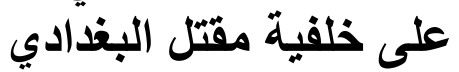

محمد سعيد شفيق مبارك

طالب دكتور اه، قسم اللغة الإنجليزية ــ كلية الآداب ـ جامعة دمياط.

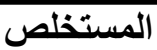

شهد القرن العشرون بعض الأنشطة المتميزة في المجالات اللغوية خاصة الدارسات النحوية و أغلب هذه الدارسات برزت في الجانب الغربي من الكرة الأرضية،

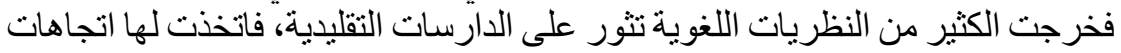

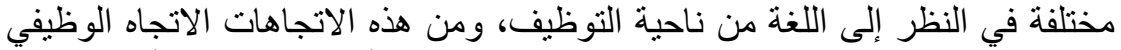

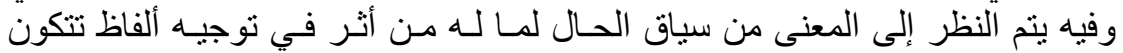

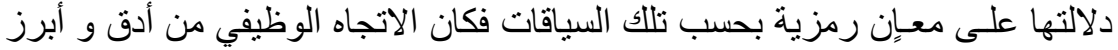

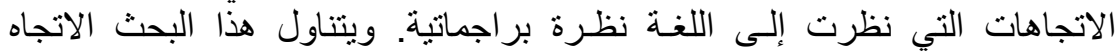

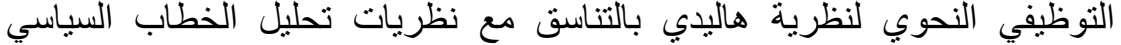

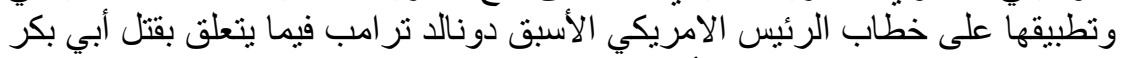

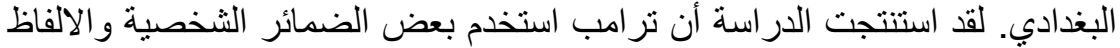
المتكررة للسخرية من أبي بكر البغدادي وصورة الإرهاب التي سقطت التهاب عند موته. الكلمات المفتاحية: البغدادي، الخطاب السياسي.

تاريخ المقالة: تاريخ استــــــــلام المقالــــة: 19 مايو 2021. تاريخ استلام النسخة النهائية: 1 يوليو 2021 ياريخ 2021. تاريخ قبــــــول المقالــــــــة: 25 يوليو 2021. 